\title{
Ruderal vegetation of the class Polygono-Poetea annuae in Kryvyi Rih (Ukraine)
}

\section{Nathalia Yeremenko}

M. H. Kholodny Institute of Botany of NAS of Ukraine, Kyiv, 2, Tereschchenkivska St., 01004, Ukraine; nathaly5755@gmail.com

\begin{abstract}
Yeremenko N. (2019): Ruderal vegetation of the class Polygono-Poetea annuae in Kryvyi Rih (Ukraine) - Thaiszia - J. Bot. 29 (1): 001-021.

Abstract: The present paper studies the ruderal vegetation of the class Polygono-Poetea annuae in Kryvyi Rih. We present the ruderal plant communities of short annual species on the open, moist to dry ecotopes. Urban landscapes remain unstudied phytosociologically despite the highly diverse habitat niches. We have carried out the comparisons of communities from other regions of Ukraine and adjacent territories. In total, two associations and two variants, belonging to alliance were identified and categorized as follows Polygono-Coronopodion (the communities with the dominance of Polygonum aviculare). The ordination analysis indicates ecological differentiation of syntaxa investigated in Kryvyi Rih. The most important of them are soil water regime $(\mathrm{Hd})$, variability of damping $(\mathrm{fH})$ and soil aeration $(\mathrm{Ae})$.

Keywords: syntaxonomy, classification, trampled vegetation, ecological differentiation.
\end{abstract}

\section{Introduction}

Polygono-Poetea annuae Rivas-Martinez 1975 is one of the clearest in the definition type of ruderal plant communities. Coenoses grow on compacted soils because of trampling and/or grazing. Plants are adapted to highly and moderately aerated soils with moderate rain and melted water drenching of soils 
with a predominance of annual plant species. Their composition and structure depend on the disturbance frequency and intensity, and it is subject to soil humidity and nitrogen content in the soil as well as the moisture and content of nutrients in the soil. Species of other classes of vegetation are common in floristic composition, particularly of Molinio-Arrhenatheretea Tx. 1937 (Taraxacum officinale), Stellarietea mediae Tx. et al. in Tx. 1950 (Ambrosia artemisiifolia, Chenopodium album, Convolvulus arvensis, Conyza canadensis, Diplotaxis muralis, Hordeum murinum, Lactuca serriola). Species of investigated class prevail in coenoflora (Lolium perenne, Plantago major, Polygonum aviculare). Communities are the initial stages of succession or form because of regression changes of natural vegetation, under the anthropic influence (there are in the dumps, in the river valleys as a result of grazing or trampling in Kryvyi Rih). The vegetation of class is cosmopolitan and is formed in North America, Eurasia, and, probably, in the tropical regions of the Southern Hemisphere (Ishbirdin 2001).

The syntaxonomy of the class is topical. Native and foreign scientists xerophytic and mesophytic vegetation, formed under the influence of trampling and grazing, united into Plantaginetea majoris Tx. et Preising ex von Rochow 1951 (Solomakha et al. 1992; Oberdorfer 1983; Moravec et al. 1995; Mirkin et al. 2008). Resistant to trampling communities of annual species in ecotopes with temperate soil humidity emphasized in Polygono arenastri-Poetea annuae Rivas-Martínez 1975 corr. Rivas-Martínez et al. 1991 (Rivas-Martínez et al. 2001; Lániková \& Lososová 2009). According to «Vegetation of Europe...» dwarf-herb vegetation of trampled habitats is considered as Polygono-Poetea annuae Rivas-Martínez 1975 Polygono arenastri-Poetalia annuae Tx. in Géhu et al. 1972 corr. Rivas-Martínez et al. 1991 (Mucina et al. 2016). Theurillat \& Moravec (1995) with the co-authors suggested classifying the contents of this syntaxon as a subclass within Stellarietea mediae. The authors described Polygono-Artemisietea austriacae Mirkin, Sakhapov et Solomeshch in Ishbirdin et al. 1988 as an analogue of investigated class in the steppe zone of the Republic of Bashkortostan, which formed under the grazing and trampling influence.

Ukrainian authors this type vegetation regarded as monotype Plantaginetea majoris, which includes the only order of Plantaginetalia majoris Tx. to Preising in Tx. 1950 with two alliances - Polygonion avicularis Br.-Bl. $1931 \mathrm{em}$. Rivaz-Martinez 1975 and Agropyro-Rumicion crispi Nordh. 1940 (Solomakha et al. 1992; Levon 1997). But local scientists consider the vegetation within two orders - Plantaginetalia majoris Tx. et Preising in Tx. 1950, Agrostietalia stoloniferae Oberdorfer in Oberdorfer et al. 1967 (Osypenko 2006; Solomakha 2008); Plantaginetalia majoris Tx. \& Preising in Tx. 1950, Potentillo-Polygonetalia Tx. 1947 (Pashkevich 2012); Plantaginetalia majoris Tx. ex von Rochow 1951, 
Potentillo anserinae-Polygonetalia avicularis Tx. 1947 (Vynokurov 2016); and within class Polygono arenastri-Poetea annuae Rivas-Martinez 1975 corr. RivasMartinez et al. 1991 Polygono arenastri-Poetalia annuae Tx. in Géhu et al. 1972 corr. Rivaz-Martinez et al. 1991, Potentillo-Polygonetalia Tx. 1947 (Bagrikova 2016). Solomakha et al. (2017) classifies trampled vegetation as class PolygonoPoetea annuae Rivas-Martinez 1975 with alliance Polygono arenastri-Poetalia annuae Tx. in Géhu et al. 1972 corr. Rivas-Martínez et al. 1991. We prefer this concept, and class Polygono-Poetea annuae means therophyte-rich dwarfherb vegetation of (semi)dry to mesophilous trampled habitats and without hemicryptophyte-rich vegetation of moist to wet habitats (which is usually ordered within the class Molinio-Arrhenatheretea).

The aim of the paper is to analyze the vegetation of Polygono-Poetea annuae from the ecologo-coenotic, synphytoindication and ordination aspects.

\section{Material and methods}

\section{Study area}

Kryvyi Rih is located in the central part of the Ukrainian crystalline massif in the steppe zone of Ukraine at the confluence of the rivers Ingulets and Saksagan that are part of the Dnipro river basin. Kryvyi Rih differs from the most Ukrainian cities with the specifics of its town planning: it extends more than $100 \mathrm{~km}$ in the meridian direction. The number of inhabitants is about 650,500. Urban area is $430 \mathrm{~km}^{2}$, only $24 \%$ of which is used for residential development (Kazakov et al. 2000). About $330 \mathrm{~km}^{2}$ is occupied by the enterprises for the processing of iron raw materials along with the other related enterprises and industrial waste, etc. (Paliy 2000). The city territory belongs to the Atlantic-continental European insufficiently humid warm region of the temperate climate zone (Alisov 1969). Atmospheric precipitation is distributed unevenly; most of it falls in summer. The average annual rainfall is $400-450 \mathrm{~mm}$ (Mykhaylenko 1982). Over-transformed chernozem (black earth) (3.5-5.5\% humus) is the basis of the soil cover of the city (Tykhonenko 2001). Average air temperature in July is $22.2^{\circ} \mathrm{C}$, in January -5.1 ${ }^{\circ} \mathrm{C}$, and annual average $+8.5^{\circ} \mathrm{C}$. The urban landscape is changed because of an intensive development of iron ore industry. Its main forms are tailings, quarries, territories of industrial enterprises, road, residential landscapes, wastelands, etc. (Yarkov 2013).

The classification of the ruderal vegetation of the class in Kryvyi Rih is based on our phytocoenological research carried out in Kryvyi Rih during 2016 and 2017. We sampled 151 of 4 to $16 \mathrm{~m}^{2}$ plot size relevés in the study area according to 
the Braun-Blanquet approach (Braun-Blanquet 1964; Westhoff \& van der Maarel 1973). Most importantly, the vegetation samples had to meet the criterion of homogeneous community structure. Plant cover was assessed in percentages (\%), converting to values on the Braun-Blanquet combined scale: $r$ - the species is extremely rare; + - the species is rare, the degree of plant cover; $1-$ plant cover up to $5 \% ; 2$ - covered from $6 \%$ to $25 \% ; 3$ - covered from $26 \%$ to $50 \%$; 4 - covered from 51 \% to $75 \%$; 5 - more than $75 \%$ (Mirkin \& Solomeshch 1989). The layers in community were distinguished by height: the first is upper herb, and the second and the third are lower herb layers.

The vegetational classification was conducted by means of Modified TWINSPAN (Roleček et al. 2009), implemented in the software package JUICE 7.0 (Tichý 2002). We used the default settings of TWINSPAN (with three pseudospecies cut levels: $0 \%, 5 \%$ and $15 \%$; minimum group size: 5; Whittaker's beta). The analysis was done in two steps. Firstly, the entire data set was processed with Modified TWINSPAN to identify the high-level syntaxa at alliance level. Secondly, each cluster with relevés from the study area was analysed separately using Modified TWINSPAN with the same parameters as above. Thirdly, the associations were identified. To identify diagnostic species the phi fidelity index was used (Chytrý et al. 2002). Fidelity was calculated using presence-absence data with standardization of all groups of relevés to equal size. Non-significant values of fidelity (less than 0.001) were removed using Fischer's exact test. Fidelity indices were calculated first for the level of association and subassociation. The diagnostic species for the alliance level were calculated after merging associations in alliances.

The proportion of affinity species of different classes in the coenoses composition was accounted when making a syntaxonomic classification of communities regarding the membership of the association to the alliance or order. The diagnosed species of the class were determined by the List of diagnostic species of classes of the plant communities dominated by vascular plants (Mucina et al. 2016). There are some recommendations regarding the wider character of diagnostic properties because of the differences in the coenotic behaviour of species on the territory of Ukraine (Solomakha et al. 2017). The necessity to review and add species to the list of species was used as diagnostic demand in surveys of the vegetation classes in Ukraine (Solomakha et al. 2017).

The identified syntaxa is compared with those previously allocated in different regions (Ishbirdin et al. 1988; Osypenko 1996; Osypenko \& Shevchyk 2001; Šilc \& Košir 2006; Pashkevych \& Fitsajlo 2009; Golovanov \& Abramova 2013). 
The method of DCA ordination was used to identify the features of communities' ecological differentiation by using the R-project program ( $\mathrm{R}$ Core Team 2012) with the Vegan package. To reflect ecological amplitude of the specific plant communities (syntaxa) and their relation to the most important environmental factors a basic static analysis was applied in program STATISTICA 10.0 using Didukh indicator values (Didukh 2011). Based on comparative analysis of scale and estimation of species distribution concerning ecological factor changes, Didukh (2011) elaborated basic indicator values, in which amplitude characteristics of species of flora of Ukraine are reflected. These characteristics have to be examined, specified and elaborated based on field and experimental data. Twelve factors are used in study and are divided into edaphic and climatic. Some of them were used by the researchers traditionally (humidity, acidity, and nitrogen content in soil), others (carbonate content in soil and plant concerning them) were elaborated firstly. Indicator values are calculated by using species presence/absence in community. Syntaxa names are specified according to the International Code of Phytosociological Nomenclature (Weber et al. 2000). Species names are given by "Vascular plants of Ukraine. A nomenclatural checklist" (Mosyakin \& Fedoronchuk 1999).

\section{Results and discussion}

Vegetation of the class of Polygono-Poetea annuae in the territory of Kryvyi Rih city is represented by 2 associations, 2 variants, belonging to one alliances and order (Table 1, 2). The classification scheme of Polygono-Poetea annuae vegetation in Kryvyi Rih:

- Polygono-Poetea annuae Rivas-Martinez 1975

- Polygono arenastri-Poetalia annuae Tx. in Géhu et al. 1972 corr. Rivas-Martinez et al. 1991

- Polygono-Coronopodion Sissingh 1969

-Eragrostio minoris-Polygonetum arenastri Oberdorfer 1954 corr. Mucina in Mucina et al. 1993

- Polygonetum arenastri Gams 1927 corr. Lániková in

Chytrý 2009 var. typicum

- Polygonetum arenastri var. Chenopodium album

- Polygonetum arenastri var. Lepidotheca suaveolens 


\section{Class Polygono-Poetea annuae and alliance Polygono arenastri-Poetalia annuae}

Class Polygono-Poetea annuae consists of ruderal dwarf-herb vegetation, formed by annual and perennial species (Rivas-Martínez 1975; Rivas-Martínez et al. 2002). The communities characterized by a simple structure, and depleted floristic composition, due to extreme environmental conditions. Intense mechanical influences cause substrate disruption and, sometimes, complete destruction of the vegetational cover. Syngenetic processes of vegetation restoration are observed. The pioneering succession stage is quite sustained in time. Communities form with the participation of species with the R- and SR-life strategy. Characteristic species of the class have the property of quickly restore plants biomass (short life cycle, high reproductive capacity). It may be found along roadsides, on sidewalks, sports and children's playgrounds. Communities belonging to one alliance were identified and categorized as follows: PolygonoCoronopodion Sissingh 1969 (the communities with the dominance of Polygonum aviculare).

\section{Association Eragrostio minoris-Polygonetum arenastri Oberdorfer 1954 corr. Mucina in Mucina et al. 1993}

The association in Kryvyi Rih region consists of stands where Eragrostis minor, Polygonum aviculare dominate. The communities have a two-layer structure. The first layer $(15-30 \mathrm{~cm})$ is composed of Ambrosia artemisiifolia, Conyza canadensis, Setaria viridis, Eragrostis minor, Lepidium ruderale. The second layer (up to $15 \mathrm{~cm}$ ) is formed by Plantago major, Polygonum aviculare. Communities are relatively abundant in the studied region, growing predominantly along the roads, on wastelands and residential areas in Kryvyi Rih. Substrate is chernozem (black earth), sometimes with proportion of crushed stones, sandy soils and anthropogenous waste. In the succession series, they replace the communities of Panico-Setarion Sissingh in Westhoff et al. 1946 and Eragrostion Tx. ex Oberdorfer 1954. In the absence of anthropic influence in time, the communities of Poetum annuae Gams 1927 and of Polygonum aviculare - Polygonetum arenastri Gams 1927 corr. Laniková in Chytrý 2009 form.

The association is rather common and well documented from various parts of Ukraine (Didukh et al. 2011; Pashkevich 2012) and in European countries (Brandes 1979; Jehlík 1986, 2008; Lániková \& Lososová 2009; Ninot et al. 2011; Borhidi et al. 2012). Relevés made in Kryvyi Rih region floristically resemble those ones made in the other parts of Ukraine, even though they lack a few species, such as Cynodon dactylon, Poa angustifolia (Didukh et al. 2011). Relevés 
Tab. 1. Shortened synoptic table of Robinietea communities of the study area with percentage frequencies and phi fidelity indices (in the superscript).

\begin{tabular}{lcccc}
\hline \multicolumn{1}{c}{ Group No } & $\mathbf{1}$ & $\mathbf{2}$ & $\mathbf{3}$ & $\mathbf{4}$ \\
\hline \multicolumn{1}{c}{ Number of relevés } & $\mathbf{4 0}$ & $\mathbf{4 2}$ & $\mathbf{3 9}$ & $\mathbf{3 0}$ \\
\hline D.s. ass. Eragrostio minoris-Polygonetum & arenastri & & & --- \\
Conyza canadensis & $0.37^{57}$ & --- & --- & --- \\
Digitaria sanguinalis & $0.47^{48}$ & --- & --- & --- \\
Eragrostis minor & $0.56^{29}$ & --- & --- \\
Lepidium ruderale & $0.25^{14}$ & --- & -- & $0.29^{100}$ \\
Plantago major & $0.29^{86}$ & $0.25^{78}$ & $0.29^{43}$ & $0.26^{100}$ \\
Polygonum aviculare & $0.25^{100}$ & $0.26^{100}$ & $0.25^{100}$ & --- \\
Setaria viridis & $0.35^{57}$ & --- & --- & \\
\hline
\end{tabular}

D.s. ass. Polygonetum arenastri var. typicum

Lolium perenne

$0.30^{44}$

$0.55^{100}$

D.s. ass. Polygonetum arenastri var. Chenopodium album

Chenopodium album

--- ---

$0.44^{86}$

D.s. ass. Polygonetum arenastri var. Lepidotheca suaveolens

Lepidotheca suaveolens

--- ---

$---$

$0.91^{100}$

\section{Other species}

Amaranthus retroflexus

\section{$0.17^{29}$}

Ambrosia artemisiifolia

$0.99^{57}$

Artemisia austriaca

$0.33^{14}$

Ballota nigra

$0.11^{29}$

Berteroa incana

$0.18^{14}$

Capsella bursa-pastoris

$0.14^{14}$

Convolvulus arvensis

Elytrigia repens

Echinochloa cruss-galli

$---$

Erysimum diffusum

$0.20^{57}$

$0.13^{29}$

$0.13^{29}$

Grindelia squarrosa

$0.19^{43}$

Iva xanthiifolia

---

Lactuca serriola

$0.18^{71}$

Melilotus albus

Plantago lanceolata

$---$

$0.10^{14}$

$0.18^{29}$

Poa angustifolia

$0.18^{29}$

Portulaca oleracea

$0.14^{57}$

---

$0.17^{29}$

Setaria viridis

$0.70^{43}$

$0.49^{44}$

$0.30^{43}$

$---$

$--$

$--$

Taraxacum officinale

---

$0.11^{11}$

---

$0.16^{71}$

---

$---$

$0.19^{17}$

Trifolium repens

$0.19^{33}$

$0.56^{44}$

$0.20^{57}$

---

$0.67^{14}$

-- $\quad 0.13^{29}$

$---$

$---$

---

$0.18^{29}$

$0.39^{50}$

---

$---$

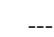

$$
--
$$

$0.16^{22}$

---

$--$

$---$

$0.70^{33}$

$0.59^{29}$

$0.12^{22}$

$---$

$0.90^{50}$

Numbers marked syntaxa: 1 - Eragrostio minoris-Polygonetum arenastri, 2 - Polygonetum arenastri var. typicum, 3 - Polygonetum arenastri var. Chenopodium album, 4 - Polygonetum arenastri var. Lepidotheca suaveolens. 
from the Czech Republic contain other species, such as Chenopodium glaucum, Puccinellia distans, Potentilla argentea, Lolium perenne.

\section{Association Polygonetum arenastri Gams 1927 corr. Lániková in Chytrý 2009 var. typicum}

Stands of this association are usually dominated by Polygonum aviculare while the other species usually appear like subdominants - Lolium perenne, Plantago major. The first layer $(10-35 \mathrm{~cm})$ layer may be developed with species Achillea submillefolium, Ambrosia artemisiifolia, Hordeum murinum, Lactuca serriola, Lolium perenne. The second layer (up to $10 \mathrm{~cm}$ ) is formed by Plantago major, Polygonum aviculare, Poa annua, Taraxacum officinale, Trifolium repens. Vegetation forms a carpet. These stands occur on ruderal sites around human settlements, along roads, in dumping places. Substrate is chernozem, sometimes with crushed stones. In succession series, they replace the communities of Eragrostion, Hordeion murini Br.-Bl. in Br.-Bl. et al. 1936 (Stellarietea mediae). In the absence of human influence in time, the communities tend to increase the area and distribution.

The association is rather common and well documented from various parts of Ukraine (Kucheryavyi et al. 1991; Papucha 1991; Levon 1999; Osypenko 1996, 2006; Osypenko \& Shevchyk 2001; Solomakha 2008; Bredikhina 2015), and in Europe (Jehlík 2008; Bordihi et al. 2012; Lániková \& Lososová 2009; Šilc \& Košir 2006; Medvecká et al. 2009) and in Russia (Cherosov et al. 2005). Relevés made in Kryvyi Rih region floristically resemble those ones made in the central and southern parts of Ukraine, even though they lack a few species, such as Amaranthus retroflexus, Atriplex patula, Sonchus oleraceus, Bromus squarrosus, Medicago sativa. Relevés from the Czech Republic contain other species, such as Coronopus squamatus, which is not present in Kryvyi Rih.

\section{Polygonetum arenastri var. Chenopodium album}

The association includes herb stands with dominant species Polygonum aviculare and Chenopodium album. It usually has two well-defined layers. The first layer $(20-45 \mathrm{~cm}$ ) is formed by Ambrosia artemisiifolia, Chenopodium album, Lactuca serriola. The second layer $(5-20 \mathrm{~cm})$ consists of species such as Hordeum murinum, Plantago major, Polygonum aviculare. Stands of this variant may be found on abandoned areas near buildings, along roads, on wastelands, garbage dumps. Substrate is chernozem. Communities are rather common in the studied region. In the absence of human influence in time, the stands tend to increase the area and distribution and form communities of the alliances Polygono- 
Chenopodion Koch 1926, Atriplicion nitensis Passarge 1978, Sisymbrion officinalis Tx. et al. ex von Rochow 1951.

The communities of variant are probably quite widespread, though yet not very well documented (Lániková \& Lososová 2009; Cherosov et al. 2005).

\section{Polygonetum arenastri var. Lepidoteca suaveolens}

This variant combines communities related to ecotopes with temporary soil water regime with dominance Lepidoteca suaveolens, Lolium perenne, Polygonum aviculare. The first layer $(10-35 \mathrm{~cm})$ is formed by Lolium perenne, Lactuca serriola. The second one $(5-10 \mathrm{~cm})$ consists of species such as Lepidoteca suaveolens, Plantago major, Polygonum aviculare. Within the city, they are sporadically described in abandoned areas near rivers, shaded sports grounds, ruderal grassplots, along with the roads. In the absence of human influence in time, the stands tend to increase the area and form communities with dominant cereal plant species.

Similar coenoses were found in the Czech Republic in the rank of the named association variant, and Lolio perennis-Matricarietum discoideae Tx. 1937 in the union Saginion procumbentis Tx. that Ohba in Géhu et al. 1972 (Lániková \& Lososová 2009).

Variants separated to show the local impact of the violation, consolidation and soil humidity on the vegetation development. The floristic composition of these communities (typicum, Chenopodium album, Lepidotheca suaveolens) is quite similar. Diagnostic species of variants - Chenopodium album, Lepidotheca suaveolens - indicate soil aeration and soil humidity, respectively. Communities of the variant Chenopodium album differ in their composition species of the class Stellarietea mediae. Communities of the variant Lepidotheca suaveolens characterized by the highest part of xerophytic and mesophytic species.

The ordination analysis is carried out to establish the ecological specificity of the communities' sites and to assess the differences in the ecotopic characteristics of the studied areas. The DCA ordination of original relevés shows that the ecological differentiation of syntaxa of the class Polygono-Poetea annuae is determined by the complex of basic ecological factors. Soil water regime (Hd), the variability of damping $(\mathrm{fH})$, and soil aeration (Ae) are the most important. Vectors of these factors are close to the DCA1 and DCA2 axes (Fig. 1). 


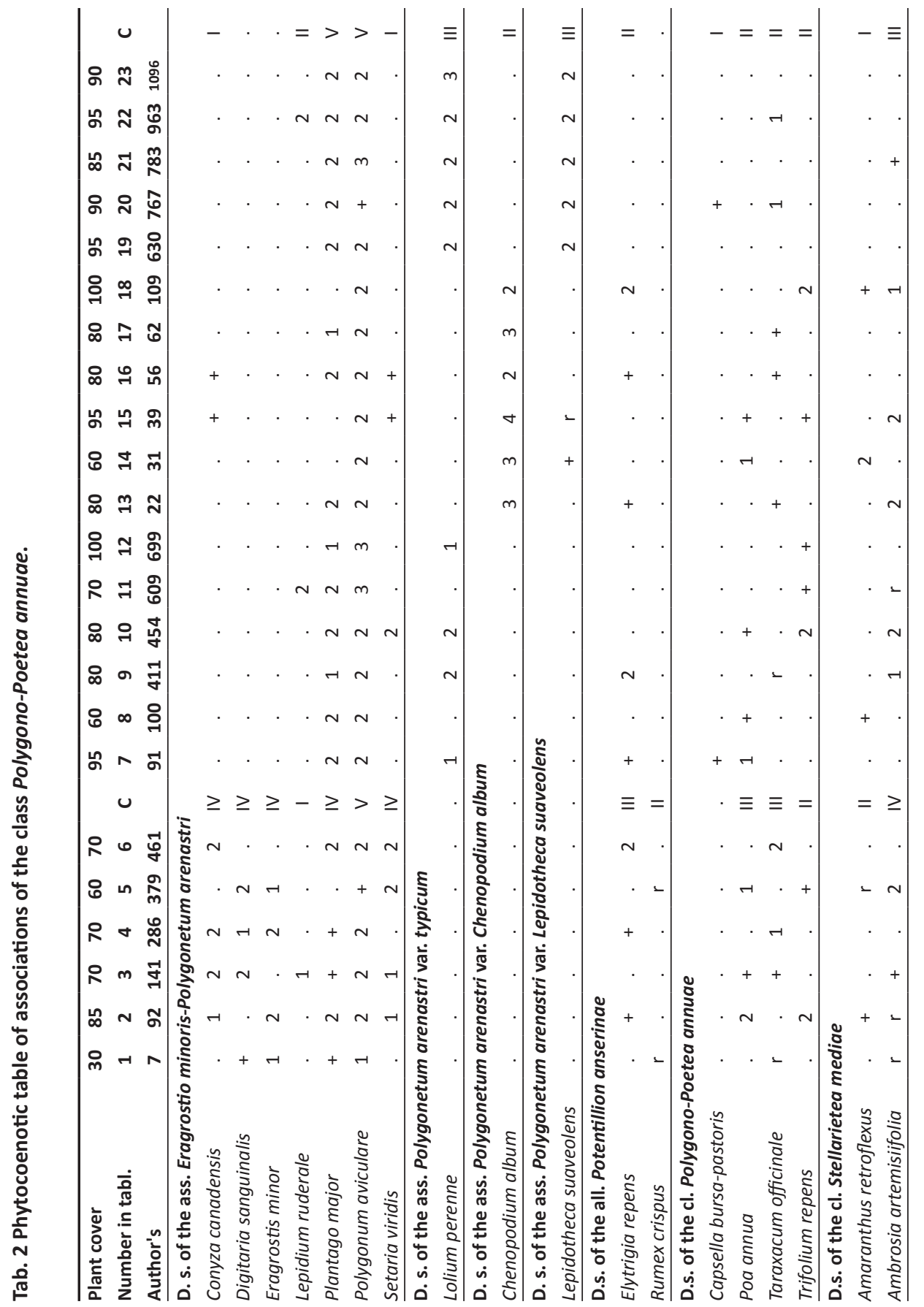




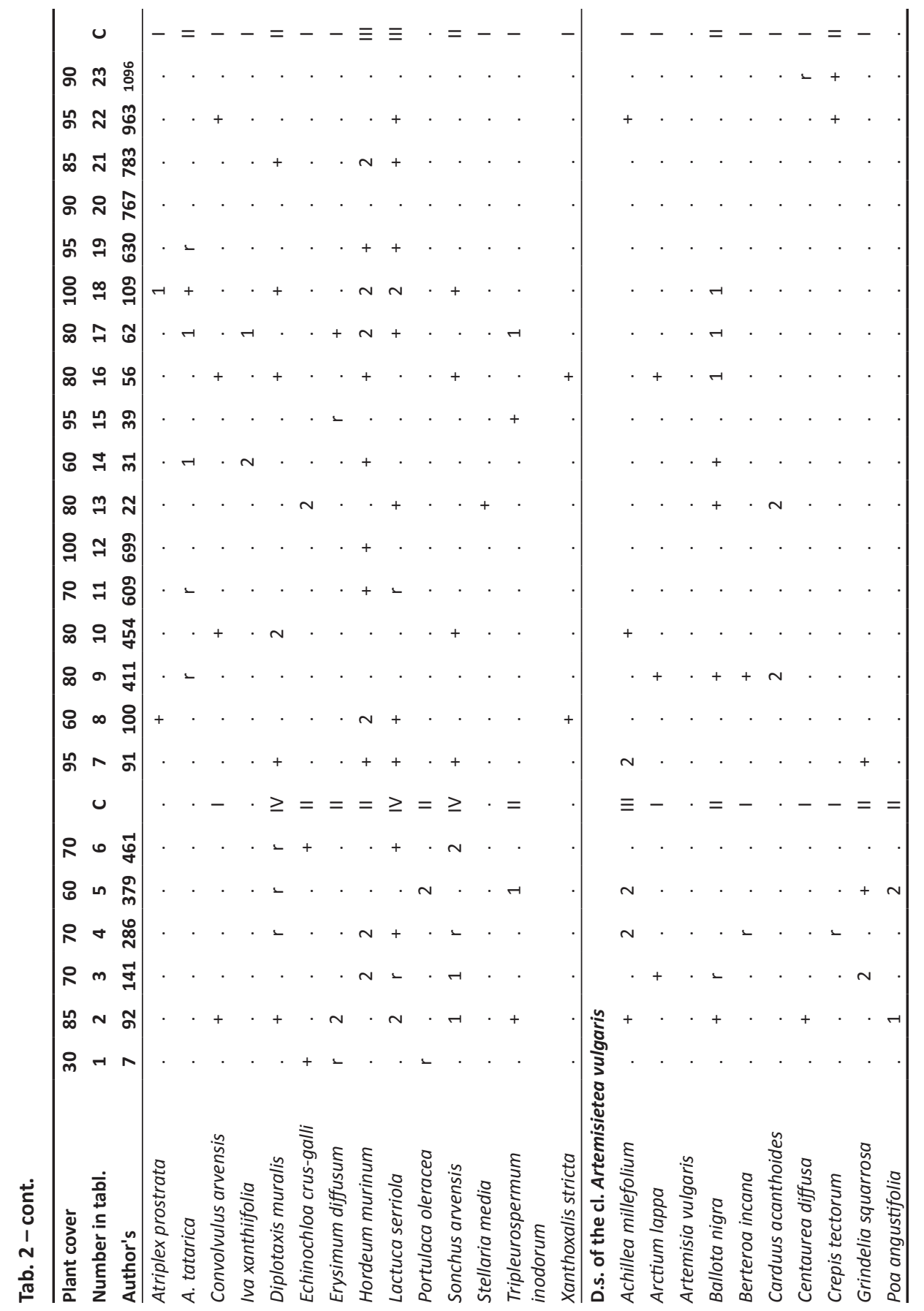




\section{Taxa in one or two relevés:}

Artemisia austriaca (+) 91; Atriplex micrantha (+) 454; Bidens tripartita (2) 56; Bolboschoenus maritimus (r) 7; Cirsium arvense (r) 100; Geum urbanum (+) 100; Plantago lanceolata (2) 379; Persicaria maculosa (r) 7; Solanum nigrum (+) 100; Sonchus oleraceus (+) 100; Trifolium pratense (2) 454; Viola hirta (+) 411.

\section{Localities of relevés:}

1 - wasteland near the gated community, $16 \mathrm{~m}^{2},(21.07 .16)$;

2-embankment of the chernoszem soils along the road on Starovokzalna street, $8 \mathrm{~m}^{2}$ (27. 07. 16);

3 -yard of a dwelling house on Svyato-Mykolaivska street, $16 \mathrm{~m}^{2}$ (28. 07. 16);

4 - plot near playground on Heroiv-pidpilnykiv street (11. 08. 16);

5 - wasteland near mine office of "ArcelorMittal Kryvyi Rih", $25 \mathrm{~m}^{2}$, (15. 08. 16);

6,10 - roadside of Vatutina street, $9 \mathrm{~m}^{2},(02.09 .16)$;

7 - roadside Starovokzalna street, $9 \mathrm{~m}^{2},(27.07 .16)$;

8 - garbage dump near a dwelling house on Tramvayna, $10 \mathrm{~m}^{2}$, (27. 07. 16);

9 - abandoned plot near the filling service station, $16 \mathrm{~m}^{2}$, (15. 08. 16);

11 - abandoned playground on the $98^{\text {th }}$ quarter, $25 \mathrm{~m}^{2},(16.07 .17)$;

12 - abandoned plot on the waterfront, $10 \mathrm{~m}^{2},(18.07 .17)$;

13 - plot near garbage dump on Starovokzalna street, $9 \mathrm{~m}^{2},(21.07 .16)$;

14 - wasteland on Kuryachoho street, $25 \mathrm{~m}^{2},(21.07 .16)$;

15 - roadside of Staroyarmarkova street, $8 \mathrm{~m}^{2}$, (22. 07. 17);

16 - roadside of gated community, $8 \mathrm{~m}^{2},(25.07 .16)$;

17 - garbage dump near Inhulets river, $8 \mathrm{~m}^{2},(26.07 .16)$;

18 - plot near near the music college, $25 \mathrm{~m}^{2},(27.07 .16)$;

19 - sports ground near school number $70,25 \mathrm{~m}^{2},(17.07 .17)$;

20 - abandoned plot near hospital, ploshcha Vyzvolennya, $16 \mathrm{~m}^{2}$, (27. 07. 17);

21 - plot near the public transport stop "PI. B. Khmelnitsky", $9 \mathrm{~m}^{2}$, (27. 07. 17);

22 - abandoned plot near the building of technical school, $12 \mathrm{~m}^{2}$, (14. 08. 17);

23 - roadside of Heroes ATO, $8 \mathrm{~m}^{2}$, (30. 08. 17) 


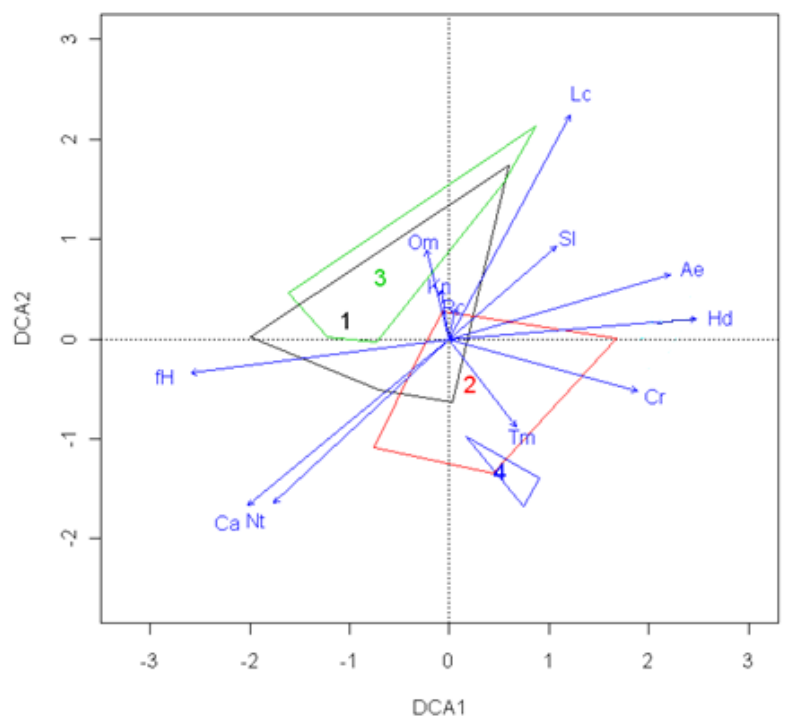

Fig. 1. The results of DCA-ordination of syntaxa of class Polygono-Poetea annuae by ecological factors: $\mathrm{Hd}$ - soil water regime, $\mathrm{fH}$ - variability of damping, $\mathrm{Rc}$ - soil acidity, $\mathrm{SI}$ - total salt regime, $\mathrm{Ca}$ - carbonate content in soil, $\mathrm{Nt}$ - nitrogen content in soil, Ae - soil aeration, $\mathrm{Tm}$ - thermal climate (thermoregime), Om - humidity, $\mathrm{Kn}$ - continentality of climate, $\mathrm{Cr}$ - cryo-climate, Lc - light. Legend: The numbers marked syntaxa: 1 - Eragrostio minoris-Polygonetum arenastri, 2 - Polygonetum arenastri typicum var. typicum, 3 - Polygonetum arenastri var. Chenopodium album, 4 - Polygonetum arenastri var. Lepidotheca suaveolens.

The phytoindication analysis of the relation of plant species to soil water regime ( $\mathrm{Hd}$ ) showed that plants of the class Polygono-Poetea annua adapted to rather dry habitats (Wnp $=75-100 \mathrm{~mm}$ ) (Table 3 ) (variables ranging from 9.6 to 11.0). Communities of Polygonetum arenastri var. Chenopodium album adap-ted to melted water drenching of soil layer where plant roots penetrate (Wnp $=100-150 \mathrm{~mm}$, variables ranging to 11.4). According to the results of the evaluation of the variability of damping $(\mathrm{fH})$, it is revealed that plants adapted to dry habitats with irregular wetting of soil layer where plant roots penetrate, or with soil small drenched by precipitations or melted waters (the variables range from 6.4 to 7.9). The results of phytoindication of the communities by relation to acidity $(\mathrm{Rc})$ indicate that plants grow on acidulous and neutral $(\mathrm{pH}=$ 6.5-7.1) soils. The values of soil acidity range from 7.5 to 9.1. By the relation of plant species to total salt regime (SI) it is indicated they grow on soils enriched with salt (150-200 mg/l) with content of $\mathrm{HCO}_{3}^{-} 4-16 \mathrm{mg} / 100 \mathrm{~g}$ of soil, and trace of $\mathrm{SO}_{4}^{-}$and $\mathrm{Cl}^{-}$in some types. The values range from 8.1 to 9.4. Communities of Polygonetum arenastri var. Chenopodium album are eutrophes and form 
on reach chernozems well enriched in salt. The results of synphytoindication analysis by the relation of plant species to carbonate content in soil ( $\mathrm{Ca}$ ) indicate that, on the one hand, plants of neutral habitats sustained to small carbonate content in soil $(\mathrm{CaO}, \mathrm{MgO}=0.5-1.5 \%)$. On the other hand, they grow on chernozems, enough enriched with carbonates $(\mathrm{CaO}, \mathrm{MgO}=1.5-5 \%)$, which are washed and can occur in forms of inclusions. The limits of the variables range from 6.2 to 7.7. Distribution of associations by the relation of plant species to nitrogen content in soil $(\mathrm{Nt})$ showed that they grow on soils enough provided with mineral nitrogen (0.3-0.4\%). Range of environmental values is from 5.9 to 7.4). The wide ecological amplitude (range 1.2 points) for the indicated factor has communities of Polygonetum arenastri var. typicum. Ecological values for aeration of soil (Ae) indicate that communities grow on weakly aerated soils. The wide ecological amplitude (range 1.5 points) for the indicated factor has communities of Polygonetum arenastri var. Chenopodium album which show plants adapted to highly aerated habitats with inclusions of broken stones.

The thermal climate $(\mathrm{Tm})$ is estimated basing on radiation balance (the quantity of heat, which falls on $1 \mathrm{~cm}^{2}$ during a year). This value varies from several to 100 $\mathrm{kcal}$ per $\mathrm{cm}^{2}$. Based on results of synphytoindication (the values range from 8.1 to 9.4), plants grow in conditions with $40-50 \mathrm{kcal} / \mathrm{cm}^{2}$. The humidity $(\mathrm{Om})$ is one of the most important ecological factors reflecting aridity - climate humidity. This factor characterizes air humidity and is linked with precipitation quantity, flowing, evaporation and transpiration, soil humidity, level of grounds waters. The humidity index integrates precipitation influence and thermal resources of the territory. This index in Kryvyi Rih is sub-aridophytic (-400 - -200). The continentality of climate (contrast regime) $(\mathrm{Kn})$ is the sum of environmental properties, determined by the influence of big area of sea and land atmospheric processes and climate formation. The results of synphytoindication show hemicontinental conditions (131-150\%). The cryo-climate $(\mathrm{Cr})$ reflects cryoregime of climate. The main meteorological elements, influencing plant hibernating, are air temperature and cloak of snow. The characteristic of winter extreme conditions is average temperature of the coldest month (it is mainly January, uncommonly February in Ukraine). The results correspond to warm types of winters $\left(-10--6^{\circ} \mathrm{C}\right)$. According to the results of synphytoindication on the light (Lc) communities consist of plants of open places, which are located under direct sunlight, sometimes lower layers are in the shade. 


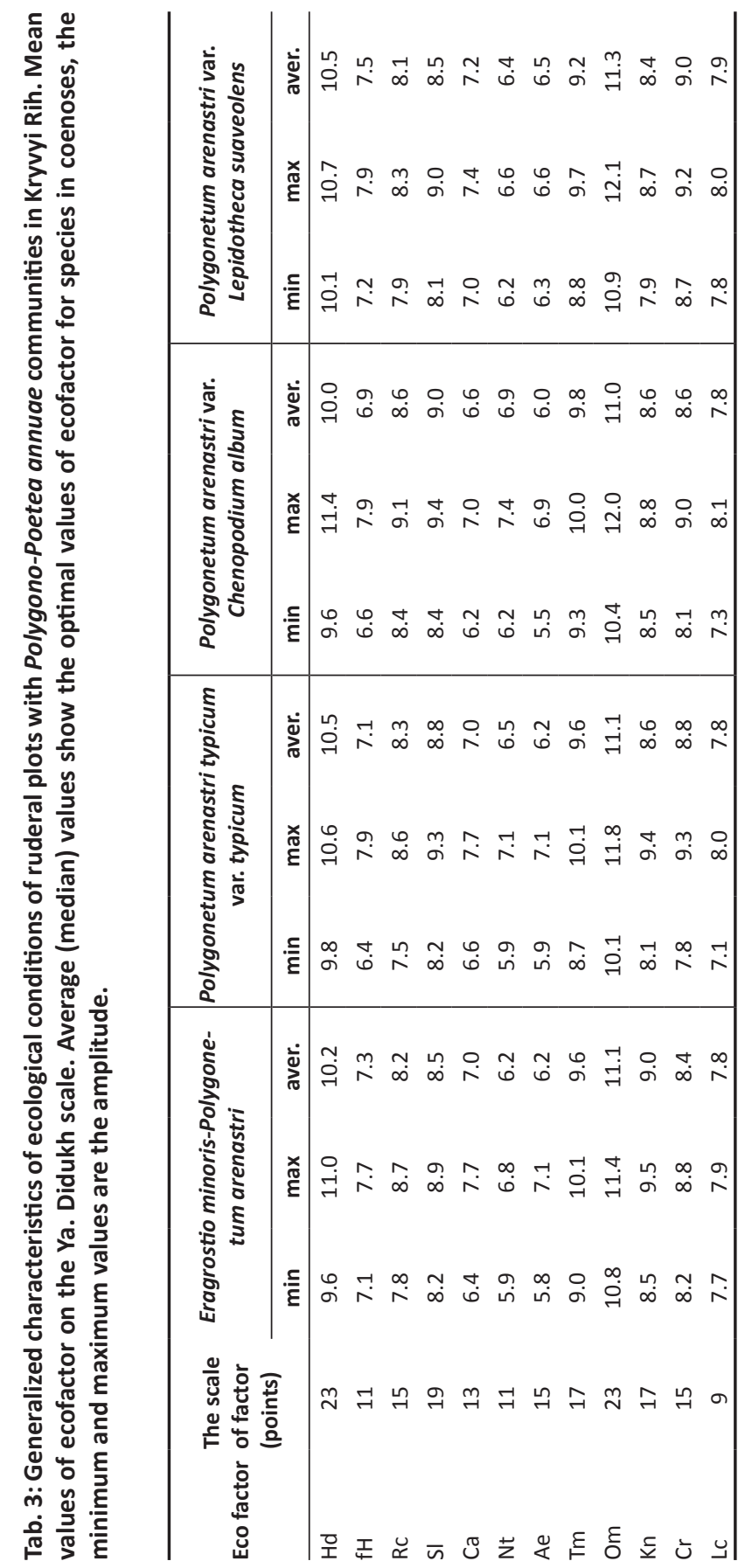




\section{Conclusions}

The Polygono-Poetea annuae vegetation class in Kryvyi Rih comprises two associations and two variants, belonging to one order and alliance. It shows a relatively low syntaxonomic diversity but covers large areas with communities belonging to the class. The phytoindication evaluation of ecotopes carried out and the most important ecological factors influencing the differentiation of communities are soil water regime $(\mathrm{Hd})$, the variability of damping $(\mathrm{fH})$, and soil aeration (Ae). The developed classification scheme will contribute to the further elaboration of syntaxa of Polygono-Poetea annuae, a critical review of the syntaxonomy of investigated class is demanded. Due to the careful care of grass plots, the syntaxa diversity of this ruderal vegetation decreases, and the frequent mowing of the roadsides may contribute to the development of the semi-natural elements of Artemisietea vulgaris. With the increase of recreational load, especially along roads and recreation areas, the area occupied by the Polygono-Poetea annuae communities will increase. It may happen due to further transformation of the communities of herbaceous semi-natural vegetation of the order Convolvulo arvensis-Agropyrion repentis Görs 1967. The feature of the formation of communities is the significant participation of alien species. It testifies to the influence of natural vegetation and the specifics of the economic activity of the region on the formation of ruderal cenoses, their composition and the ecological structure in general. It shows the influence of (semi)natural vegetation and the specifics of the economic activity of the region on the formation of ruderal coenoses, their floristic composition and the ecological structure in general. So, forecasts of dynamic processes, in particular under the influence of anthropic factors should be made.

\section{References}

Alisov B.P. (1969): Climate of the USSR. - Moscow, Vysshaya shkola, 104 pp. [in Ukrainian]

Bagrikova N.A. (2016): The study of the synanthropic vegetation of the Crimean peninsula from the item of the ecological-floral approach: the state of the issue, the classification of communities and the prospects for research. Collection of scientific papers GNBS, 2016, 143: 25-58 [in Russian]

Borhidi A., Kevey B. \& Lendvai G. (2012): Plant communities of Hungary. Akadémiai Kiadó, Budapest, 525 pp.

Brandes D. (1979): Die Ruderalgesellschaften Osttirols. Beiträge zur Kenntnis der Ruderalvegetation Mitteleuropas, III. - Mitt. Florist.-Soziol. Arbeitsgem., N. F. 21: 31-47. 
Braun-Blanquet J. (1964): Pflanzensoziologie. Grundzuge der Vegetationskunde. 3 Aufl. - SpringerVerlag, Wien-New York, 865 pp.

Bredikhina Yu.L. (2015): Spontaneous vegetation of the city of Melitopol: syntaxonomy, phytomeliorative value and ways of optimization: author's abstract. - Dis Cand. agricultural Sciences: special 06.03.01 "Forest crops and phytomelioration". Lviv, 18 pp. [in Ukrainian]

Cherosov M.M., Sleptsova N.P., Mironova S.I. (eds.) (2005): Syntaxonomy of the synanthropic vegetation of Yakutia, Ed. E.G. Nicolin. - Yakutsk, 575 pp. [in Russian]

Chytrý M. (ed.) (2009): Vegetace České Republiky. 2. Ruderální, plevelová, skalní a sut́ová vegetace. - Praha, 524 pp.

Didukh Ya.P. (2011): The ecological scales for the species of Ukrainian flora and their use in synphytoindication. - Kyiv. Phytosociocentre, $176 \mathrm{pp}$.

Didukh Ya.P., Fitsajlo T.V., Korotchenko I.A., lakusgenko D.M. \& Pashkevych N.A. (2011): Biotopes of forest and forest-steppe zones of Ukraine. - LLC Macros, Kyiv, 288 pp.

Ishbirdin A.R. (2001): Ekologo-geograficheskiye zakonomernosti formirovaniya sinantropnykh flor i rastitelnosti selitebnykh territoriy Rossii. Abstract of Thesis for Doctor Degree. Moscow - Ecological-geographical principles of the formation of synanthropic flora and vegetation of populated areas in Russia [in Russian]

Ishbirdin A.R., Mirkin B.M., Solomeshch A.I., Sakhapov M.T. (1988): Syntaxonomy, ecology and dynamics of ruderal communities in Bashkortostan. - Ufa, 161 pp. [in Russian]

Jehlík V. (1986): The vegetation of railways in Northern Bohemia (eastern part). - Academia, Praha.

Jehlík V. (2008): Übersicht über die synanthropen Pflanzengesellschaften und ihre Verbreitung in Flusshäfen Mitteleuropas (Vorläufige Mitteilung). Braunschweiger geobotanische Arbeiten, 9: 311-324.

Golovanov Ya.M. \& Abramova L.M. (2013): The vegetation of Salavat (Republic of Barshkotorstan). IV. Synanthropic vegetation (the classes of Polygono arenastri-Poëtea annuae, Galio-Urticetea, Robinietea). - Vegetation of Russia, 22: 11-20. [in Russian]

Kazakov V.L., Smetana M.H., Shypunova V.O., Paranko I.S. et al. (2000): Natural geography of Kryvbas. - Oktan-Print, 137 pp. [in Ukrainian]

Kucheryvyi V.O., Solomakha V.A., Solomakha T.D., Shelyah-Sosonko Yu.R., Kramarets V.O. (1991): Syntaxonomy of ruderal vegetation in Lviv. - Ukr. Bot. J. 48 (3): 48-54 [in Ukrainian] 
Levon O.F. (1997): Syntaxonomy of the ruderal vegetation of Yalta. The class Plantaginetea majoris. Ukrainian Phytocenological Collection. Kyiv, Series A, 1(6): 75-81 [in Ukrainian]

Levon O.F. (1999): Synanthropic vegetation of the territory of Great Yalta: Author's abstract. - Dis ... Cand. biology sciences: special 03.00.05 "Botany". Kyiv, 16 pp. [in Russian]

Medvecká J., Zaliberová M. \& Jarolímek I. (2009): Ruderal Vegetation of the Horná Orava Region 1. Bidentetea tripartitae, Polygono arenastri-Poetea annuae, Molinio-Arrhenatheretea, Stellarietea mediae and Artemisietea vulgaris. - Thaiszia - J. Bot. 19: 91-129.

Mirkin B.M. \& Solomeshch A.I. (1989): The syntaxonomy of synanthropic vegetation: current state and development tendencies. - J. Gen. Biol. 50(3): 379-387. [in Russian]

Mirkin B.M., Yamalov S.M., Naumova L.G., Suyndukova G.Ya. (2008): Principles of classification of synanthropic communities, the role of the deductive method. Classification procedure. - In: The synanthropic vegetation of the Trans-Ural region and the Mountain-Forest Zone of the Republic of Bashkortostan: phytorectivation effect, syntaxonomy, dynamics. - Ufa, Gilem, p. 62-78 [in Russian]

Moravec J., Balátová-Tuláková E., Blažková D., Hadač E., Hejný S., Husák Š., Jeník J., Kolbek J., Krahulec F., Kropáč Z., Neuhäusl R., Rybníček K., Řehořek V., Vicherek J. (1995): Rostlinná společenstva České republiky a jejich ohrožení. Ed. 2. - Severočeskou Přír., Př́l., 1: 1-206.

Mosyakin S.L. \& Fedoronchuk M.M. (1999): Vascular plants of Ukraine. A nomenclatural checklist. - Kiev, 1999, xxiii + 345 pp.

Mucina L., Bültmann H., Dierßen K., Theurillat J.-P., Raus T., Čarni A., Šumberová K., Willner W., Dengler J., Gavilán García R., Chytrý M., Hájek M., di Pietro R., lakushenko D., Pallas J., Daniëls F.J.A., Bergmeier E., Santos Guerra A., Ermakov N., Valachovič M., Schaminée J.H.J., Lysenko T., Didukh Y.P., Pignatti S., Rodwell J.S., Capelo J., Weber H.E., Solomeshch A., Dimopoulos P., Aguiar C., Hennekens S.M., Tichý L. (2016): Vegetation of Europe: hierarchical floristic classification system of vascular plant, bryophyte, lichen, and algal communities. Applied Vegetation Science 19(1): 3-264. DOI: 10.1111/ avsc. 12257

Mykhaylenko M.M. (1982): Fundamentals of Agrometeorology. - Vyshcha Shkola, Kyiv, 192 pp. [in Ukrainian]

Ninot J.M. (ed.) (2011): Syntaxonomic conspectus of the vegetation of Catalonia and Andorra. II: Ruderal communities. - Acta Bot. Barc. 53: 113-189. 
Oberdorfer E. (ed.) (1983): Süddeutsche Pflanzengesellschaften Teil III: Wirtschaftswiesen und Unkrautgesellschaften. Ed. 2. - Gustav Fischer Verlag, Stuttgart/New York.

Osypenko V.V. (1996): Spontaneous vegetation of the city of Cherkasy. The class

Plantaginetea, Ukrainian Phytocenological Collection. Kyiv, Series A, 3: 7881 [in Ukrainian]

Osypenko V.V. (2006): Spontaneous vegetation in Cherkasy: author's abstract.

- Dis ... Cand. biology Sciences: special 03.00.05 "Botany". Kyiv, 20 p. [in Ukrainian]

Osypenko V.V. \& Shevchyk V.L. (2001): Spontaneous vegetation of Cherkasy. 6.

Ruderal vegetation of the coastal part of Cherkasy. Ukrainian Phytocenological

Collection, Kyiv, Series A, 1(17): 108-121 [in Ukrainian]

Paliy V.M. (2000): Dosvid kompleksnoi otsinky ta kartohrafuvannia faktoriv tekhnohennoho vplyvu na pryrodne seredovyshche mist Kry-voho Rohu ta Dniprodzerzhynska. - Feniks, Kyiv, 110 pp. [in Ukrainian]

Papucha I.V. (1991): Ruderal vegetation of Chernihiv. - Ukr. Bot. J. 48(2): 39-41 [in Ukrainian]

Pashkevich N.A. (2012): Trampling vegetation (Plantaginea majoris R. Tx. et Prsg. in R.Tx. 1950) in Ukraine. - Izvestiya Samara Scientific Center of the Russian Academy of Sciences 14, 1 (6): 1508-1511 [in Russian]

Pashkevych N.A. \& Fitsajlo T.V. (2009): Synanthropic vegetation of transformed habitats of Chernigov region. - Ukr. Bot. J. 66 (2): $213-219$ [in Ukrainian]

Rivas-Martínez S. (1975): Sobre la nueva clase Polygono-Poetea annuae. Phytocoenologia, 2: 123-140.

Rivas-Martínez S., Díaz T.E., Fernández-González F., Izco J., Loidi J., Lousã M., Penas Á. (2002): Vascular plant communities of Spain and Portugal. Addenda to the Syntaxonomical checklist of 2001. - Itin. Geobot. 15(1-2): 5-922.

Roleček J., Tichý L., Zelený D. \& Chytrý M. (2009): Modified TWINSPAN classification in which the hierarchy respects clusters heterogeneity. $-\mathrm{J}$ Veg. Sci. 20(4): 596-602. DOI: 10.1111/j.1654-1103.2009.01062.x

Šilc U. \& Košir P. (2006): Synanthopic vegetation of the city of Kranj (Central Slovenia). - Hacquetia 5/1: 213-231.

Solomakha V.A. (2008): The syntaxonomy of vegetation of the Ukraine. The third approximation. - Phytosociocentre, Kyiv, 296 pp. [in Ukrainian]

Solomakha V.A. Kostylov O.V., Shelyah-Sosonko Yu.R. (1992): Synanthropic vegetation of Ukraine. - Naukova dumka, Kyiv, 252 pp. [in Ukrainian]

Solomakha I.V., Shevchyk V.L., Solomakha V.A. (2017): Review of the higher vegetation units and diagnostic species of Ukraine according to the BraunBlanquet approach. - Phytosociocenter, Kyiv, 116 pp. [in Ukrainian] 
Theurillat J.-P. \& Moravec J. (1995): Index of new names of syntax published in 1992. - Folia Geobot. Phytotax. 30: 331-362. DOI: 10.1007/bf02803716

Tichý L. (2002): JUICE, software for vegetation classification. - J. Veg. Sci. 13: 451-453. DOI: 10.1111/j.1654-1103.2002.tb02069.x

Tykhonenko D.H. (2001): On the classification of soils in Ukraine. - Edaphology, 1(1-2): 15-22.

Vynokurov D.S. (2016): Vegetation of The Valley of Ingul River: synthaxonomy, dynamics and protection: Dis. Cand. Biology Sciences: special 03.00.05 "Botany". Kyiv, 198 pp. [in Ukrainian]

Weber H.E., Moravec J. \& Theurillat J.-P. (2000): International Code of Phytosociological Nomenclature. 3rd edition. - J. Veg. Sc. 11: 739-768. DOI: $10.2307 / 3236580$

Westhoff V. \& van der Maarel E. (1973): The Braun-Blanquet approach. - In: Whittaker, R.H. (ed.): Handbook of vegetation science, part 5, Classification and ordination of communities. - Junk, The Hague: 617-726.

Yarkov S.V. (2013): The development of 20-40-year-old mixed on the substrate iron dumps landscapes in Kryvorizhzhya. -Scientific notes of Ternopil national Pedagogical University. Series Geography 2(35): 23-30 [in Ukrainian] 
Checklist

Achillea submillefolium Klokov \& Krytzka

Amaranthus retroflexus L.

Ambrosia artemisiifolia $\mathrm{L}$.

Artemisia austriaca Jacq.

Atriplex patula $\mathrm{L}$.

Atriplex tatarica L.

Ballota nigra L.

Bromus squarrosus L.

Chenopodium album L. agg.

Chenopodium glaucum L.

Convolvulus arvensis L.

Conyza canadensis (L.) Cronq.

Conyza canadensis (L.) Cronq.

Coronopus squamatus (Forssk.) Asch.

Crepis tectorum $\mathrm{L}$.

Cuscuta campestris Yunck.

Cynodon dactylon (L.) Pers.

Digitaria sanguinalis (L.) Scop.

Diplotaxis muralis (L.) DC.

Elytrigia repens (L.) Nevski

Eragrostis minor Host

Erysimum diffusum Ehrh.

Grindelia squarrosa (Pursh) Dunal

Hordeum murinum L.

Lactuca serriola L.

Lactuca serriola L.

Lepidium ruderale $\mathrm{L}$.

Lepidoteca suaveolens (Pursh) Nutt.

Lepidotheca suaveolens (Pursh) Nutt.

Lolium perenne L.

Lolium perenne L.

Medicago sativa $\mathrm{L}$.

Plantago major L.

Plantago major L.

Poa angustifolia L.

Poa annua $\mathrm{L}$.
Polygonum aviculare L. s.str.

Polygonum aviculare L. s.str.

Potentilla argentea $\mathrm{L}$.

Puccinellia distans (Jacq.) Parl.

Setaria viridis (L.) P.Beauv.

Sonchus arvensis L.

Sonchus oleraceus L.

Taraxacum officinale Wigg. agg.

Trifolium repens $\mathrm{L}$.
Received: February $15^{\text {th }} 2018$

Revised: January 23 $3^{\text {rd }} 2019$

Accepted: January $29^{\text {th }} 2019$ 